\title{
The Kalinga State University Human Resources Training Needs: An Analysis
}

\section{Marilou B. Adora, Jessie Grace M. Sannadan, Jovita E. Saguibo, Maria Cyrila C. Bawer}

Kalinga State University, Philippines

Received: 29 Sep 2020; Received in revised form: 19 Dec 2020; Accepted: 25 Dec 2020; Available online: 31 Dec 2020 (C)2020 The Author(s). Published by Infogain Publication. This is an open access article under the CC BY license (https://creativecommons.org/licenses/by/4.0/).

\begin{abstract}
This study looked into the training/seminar needs of the human resources or Kalinga State University employees. Data were collected from the one hundred ninety-five (195) employees who represented the university's three campuses: the Bulanao Campus/ the main campus, the Dagupan Campus, and the Rizal Campus. The study made use of frequency and ranking. It was found that there are various needs of the teaching group and non-teaching staff. Their needs varied since they have different functions. However, there are needs identified which are the same though at a different level. It is an indication that they, both groups of respondents, need training/seminars for updates and performance improvement. Finally, these identified training needs were used to prepare the design for future implementation, which is expected to improve employees' performance that will level up the university's status.
\end{abstract}

Keywords-training needs, human resource, $\mathrm{KSU}$.

\section{INTRODUCTION}

Confucius had left humanity his wisdom, "Give a person a fish, and you feed him for a day, teach a person to fish, and you feed him for a lifetime." In today's climate in the academic institutions and the growth in technology with its effect on the economy and global society, the need for training to upgrade and upskill employees is more pronounced for better and efficient services.

Kalinga State University is a young and fast-growing higher education institution where its human resources need to be updated with the trends of quality education and services to be at par with other Higher Education Institutions in the Association of Southeast Asian Nations (ASEAN). However, it entails enough funds to fulfill and offer it to all employees in a different arena.

In such a case, it is impossible for KSU, with its large number of employees, to send all concerned faculty and staff to attend training and seminars in different venues considering its limited resources, which may be depleted if employees' sending is unlimited. So, to maximize the fund extended by ISSN: $2456-7620$ the government, it sends only one or two in each invitation to represent the whole university. It may be international, national even in local settings if necessary for the growth of the employees and the institution. In this case, the university can earn savings that can be used to serve other purposes. The participants are asked to re-echo for others to be also updated on what they have learned. Thus, it is more economical on the university's part to ensure that workers are armed with quality output tools.

As Kalinga State University continuously grows with its population, it follows that it should also grow in terms of other facilities. The human resources should also be armed with what they use to produce clients that can be globally competitive. Hence, offering them training and seminars could help a lot in their development. Offering them training and seminars helps boost their morale and revive their enthusiasm in performing their job.

In his study, Beesley (2011) mentioned that today's work environment requires employees to perform complex tasks efficiently, cost-effective, and safe. Training is needed 
when employees do not perform up to a certain standard or at an expected performance level. The discrepancy between the actual level of job performance and the expected level of job performance indicates a need for training. Determining training needs is the first step in a uniform method of instructional design.

He added that successful training needs analysis would determine employees who need training and what kind of training is needed. It is counter-productive to offer training to employees who do not need it or offer the wrong training. Thus, training needs analysis helps to put the training resources to fair use.

An agency offering seminars and training to its human resources is investing because the prime goal is to become more effective or more productive workers. Other goals may also be making good relationships between and among workers, so employees know they are valued and feel more importance and satisfaction in their jobs. Offering such to employees gives them opportunities to revive, refresh, add their knowledge, and upskill them to work with new and different tasks without coaching them and even without their supervisors.

Relevant Trainings and seminars to be offered to employees make them independent and motivated and uplift the office's status when they perform their work efficiently and effectively.

In such a case, as one of the state colleges and universities, KSU will be seen as one that develops and retains faculty and staff if it has the correct, healthy, and consistent policy in training and seminar offerings. Hence, the Human Resource Development functions in organizations must pay enough attention and think about the process. Only where there is a comprehensive plan to train employees according to their needs and align these needs with organizational goals would ensure real progress for the organizations (managementstudyguide.com).

In Kalinga State University, an office is created to look into its human resources training and professional development. It is then necessary to look into the employees' training/seminars needs since the administration believes that this training needs assessment and analysis works best in organizations. It will give a quick assessment of employees' training needs to ensure that all employees have the upgraded skills needed to perform the job efficiently and effectively.

The researchers aimed to determine the training needs of KSU employees so that in the future, the university has a basis of what will be strengthened and what trainings be offered, and who will be given training/seminars among its ISSN: 2456-7620 human resources. There is a record to run to, which will speak on the employees' needs.

\section{METHODOLOGY}

A descriptive type of research was used in this study conducted in Kalinga State University with the employees from the three campuses as the respondents. A questionnaire was used to gather data. The researchers conducted personal interviews to validate the results of the survey and to augment the discussions. An online survey was also used. The data were tabulated and analyzed.

\section{RESULTS AND DISCUSSIONS}

The following tables below reveal the results of the training needs of the Kalinga State University training needs.

Table 1. Training/seminar Needs/Preferences of the KSU Faculty

\begin{tabular}{|c|c|c|}
\hline Needs & Teaching & Rank \\
\hline $\begin{array}{ll}\text { 1. } & \begin{array}{l}\text { Strategic } \\
\text { skills }\end{array}\end{array}$ & 182 & 1 \\
\hline 2. Stress Management & 181 & 2 \\
\hline 3. Supervisory Skills & 181 & 3.5 \\
\hline 4. Presentation Skills & 164 & 3.5 \\
\hline 5. Solid Waste Management & 163 & 5 \\
\hline 6. Compensation & 161 & 6 \\
\hline $\begin{array}{ll}\text { 7. Employee Performance } \\
\text { Management }\end{array}$ & 160 & 7 \\
\hline $\begin{array}{l}\text { 8. Climate change \& its risk to } \\
\text { the environment }\end{array}$ & 138 & 8 \\
\hline $\begin{array}{l}\text { 9. Health and wellness for } \\
\text { teachers }\end{array}$ & 105 & 9 \\
\hline 10. Orientation & 96 & 10 \\
\hline $\begin{array}{l}\text { 11. Instructional Materials } \\
\text { Development }\end{array}$ & 91 & 11 \\
\hline 12. Gender and Development & 90 & 12 \\
\hline 13. 4.0 Industrial Technology & 89 & 13 \\
\hline 14. Grievance Procedure & 84 & 14 \\
\hline 15. Costumer Service Skills & 82 & 15 \\
\hline 16. Workplace Ethics & 78 & 16 \\
\hline 17. Research and Extension & 70 & 17 \\
\hline
\end{tabular}




\begin{tabular}{|l|l|l|}
\hline 18. Conflict Management & 64 & 18 \\
\hline 19. Cultural Diversity & 43 & 19 \\
\hline 20. Workplace violence & 24 & 20 \\
\hline 21. Hiring \& firing Procedures & 23 & 21 \\
\hline 22. Recruitment and retention & 20 & 22 \\
\hline 23. Sexual Harassment & 12 & 23 \\
\hline
\end{tabular}

Most of the faculty members want to have training in strategic planning, as disclosed on the table. In KSU, every college or unit plans for their own college's activities basing on that which was given by the higher echelon. In this case, the faculty wishes to have enough planning skills to plan for their college's best. According to Greenberg, employees moving up the ladder need to be trained on managerial skills and leadership skills. All this means that each employee has a real need to train on either technical skills or soft skills.

In an interview conducted on why they want strategic or organizational planning, one answered that he wants to plan for the university. Another said he wants to be aware of what will happen next to the university in the future. Another said that he could also give his inputs in the plans since more heads are better than a few. Related answers were given. A reading made by the researchers says that strategic planning is "a structured approach to establishing an organization's direction and anticipating the future. It means that the employees interested in joining this kind of seminar or training have a point.

Next to the highest preferred topic to be attended is stress management. This finding means that the employees are suffering stress in performing their job to know how to handle it. An individual should accept that he cannot control all events to happen, but it could also be managed. In this case, the faculty should be educated on handling stresses they encounter in their jobs(webmd.com).

Equally preferred with stress management is a seminar on supervisory skills. While it is true that faculty are trained to supervise because it is a part of their work managing their students, they still believe that they lack the skill, according to the results of this survey. An interview was answered of information that today's young generation is different, so there is a need to be updated to handle them in the way it should be. An aiming leader also

Another most preferred topic is presentation skills. Since the respondents are teachers, they need to be updated in presenting lessons for their clients to learn the lessons they give. Today, learners have different styles that the teachers have to consider. They have to be skilled in

With the growing population of the university, and the community as a whole, the respondents were concerned about solid waste management, so they need to be upskilled with managing garbage properly to help maintain the environment's cleanliness. Making surroundings of the university conducive to learning and integrating some for their learners to be aware of solid waste management.

Compensation is also one that attracted the interest of the KSU faculty. An interview was done since it is also a knowledge that faculty or teachers (CHED) receive higher than others. One said it is not the figure that counts. It is how they were deducted of tax and other things that are removed from their salaries. Meaning they want to be knowledgeable as to the computation of their deductions.

Employee performance management is next. It is essential to manage and maintain the teachers' performance because once this is not given attention, many will be affected by their students' performance in class and even in the board examinations. If this is so, then the status of the university will also be affected. That when this is not given attention, a chain reaction will take place.

Learners have more hours in school than at home, so the teachers need to attend seminars related to climate change and its risk to the environment to be disseminated to learners. The learners will be aware of climate change and its risk to the environment, and that they will also help in disseminating to their family members about it. In a study conducted in South Africa by Averchenkova et al. (2019), they found that in this place, limited public sector capacity and dedicated financial resources are hampering climate change governance. If learners help in this endeavor, at least it will be a help to the government. Hence, most of the faculty members of KSU are wise and concern about their environment for selecting this as one of the top ten seminars in the university.

Health and wellness are the top nine among the choices of the teachers on seminars. Teachers work in the classroom and work with papers after. It gives the possibility of acquiring different illnesses, so it is also good to attend seminars like this to balance work and health and anticipate such a kind. A study on health and wellness (Alber, 2019) stressed that When Teachers Experience Empathic Distress, mindfulness and compassion are effective self-care strategies 
for teachers who work with students who routinely experience trauma.

Besides, Lee (2019) cited in her study that a new survey by Education Week Research Center shows that teachers feel their schools do not have adequate support for their students' social and emotional needs.

Orientation. It needs to be offered primarily to the newly hired faculty to be correctly oriented on the university's policies. In an interview made for this purpose, they want to attend because they want to be oriented toward the university's policies. The do's and don'ts of an employee so that they will be appropriately guided. A reading from an article (https: //oregonstate.edu/ copyright) states that, without orientation, a new employee sometimes feels uncomfortable in his/her new position and takes longer to reach his/her full potential.

The twelfth preferred by the faculty is gender and development. Today's trend is to integrate GAD in curricula or lessons where it could be, so this is very important to attend. It implies that many of the faculty are not yet aware of gender and development's supposed integration to possible lessons.

The other seminars stated on the table are not so important to the teachers, but some also need them to perform their jobs well.

Table 2. Training/seminar Needs/Preferences of the KSU Non-Teaching Employees

\begin{tabular}{|l|c|c|}
\hline \multicolumn{1}{|c|}{ Needs/Topics } & $\begin{array}{c}\text { Non- } \\
\text { Teaching }\end{array}$ & Rank \\
\hline 1. Solid Waste Management & 56 & 1 \\
\hline 2. Costumer Service Skills & 55 & 2 \\
\hline 3. Stress Management & 53 & 3 \\
\hline 4. Compensation Performance & 49 & 4 \\
\hline 5. $\begin{array}{l}\text { Employee } \\
\text { Management }\end{array}$ & 47 & 6 \\
\hline 6. Climate change \& its risk to the & 45 & 7 \\
\hline 7. $\quad$ Health and wellness for teachers & 46 & 8 \\
\hline 8. $\quad$ Hiring \& firing Procedures & 41 & 9 \\
\hline 9. $\quad$ Recruitment and retention & 28 & 10 \\
\hline 10. Conflict Management & 25 & 11.5 \\
\hline 11. Workplace Ethics & & 11.5 \\
\hline 12. Gender and Development & & \\
\hline
\end{tabular}

ISSN : 2456-7620

\begin{tabular}{|l|c|c|}
\hline 13. Workplace violence & 24 & 13 \\
\hline 14. Orientation & 22 & 14 \\
\hline 15. 4.0 Industrial Technology & 21 & 15 \\
\hline 16. Supervisory Skills & 19 & 16 \\
\hline 17. Cultural Diversity & 17 & 17 \\
\hline 18. Strategic Planning/Org'l skills & 16 & 18 \\
\hline 19. Sexual Harassment & 15 & 19 \\
\hline 20. Grievance Procedure & 11 & 20 \\
\hline 21. Presentation Skills & 9 & 21 \\
\hline 22. Research and Extension & 5 & 22 \\
\hline 23. Instructional Materials & 2 & 23 \\
\hline Development & & \\
\hline
\end{tabular}

Solid waste management is the topmost preferred to be attended by the non-teaching staff. It is the concern of all. The result implies that most of the employees are concerned with the university's cleanliness and orderliness. In this group, where the utility personnel come from, they need this kind of seminar to handle garbage properly, especially with the institution's fast-growing population. An article (school today) shared that millions of great teens appreciate the magnitude of the waste problem and do the right things to help. But we can do more and get others who are not doing well to do better.

Service customer skills are the second rank seminar in which most of the non-teaching staff preferred. It means that because most of the paper transactions are their primary concern, they need to be refreshed of this kind of seminar to serve clients with service excellence. A blog from customer service (2015) mentioned that, in most cases, customer service representatives must be able to assist various personalities and characters. At the same time, they must reflect the organization's core values and adhere to the company culture.

Stress Management is the third in rank. Daily routine in an office facing different personalities with different cultures destroys employees' moods most of the time. It is mentioned during a conversation with one of the employees of the university. That is why this was chosen to be offered thru a seminar. 
Compensation. It is always nice for employees to know how they are compensated, especially those hired on a contractual basis, to know what they receive when it is time to be paid. It is the right of the employees to be informed of their compensation.

Employee performance management is $5^{\text {th }}$. Through an interview, they need to attend such a seminar because they need to know and understand what is to be achieved in their work field. And so that they will also understand what they are rating in their performance rating.

As citizens, they are aware of their responsibility to their environment, Climate change \& its risk to the environment. The university's nonteaching staff should also be aware of climate change and its risk to the environment to minimize mother earth destruction.

Health and wellness. It is the seventh most preferred seminar by the non-teaching. While sitting in their offices working on their daily routine, they need to know what they should do to maintain their health. Mental illness affects each person differently. All individuals in the workplace need to be aware of potential contributing factors to mental health issues and strategies to maintain a positive pathway to mental health and encourage early reporting of symptoms(http://www.bodycare.com.au/).

Hiring \& firing Procedures and Recruitment and retention are the next preferences of the non-teaching staff are on hiring and firing procedures. The researchers interviewed a group of non-teaching staff about this particular topic because, seemingly, the expected to prefer this are only those in the administration's key positions. Here are some of their answers: to anticipate those that may put them to disqualifications for promotion; to be aware of how and why an employee is fired; when an employee is fired, are there claims to be received?

Conflict Management. In any organization, conflict among and between employees can't be avoided, and if this is not given immediate attention, it may create disturbances and waste of time, money, and effort. Interviews were also done with some staffs, and they mentioned about: so that when there are cases in the future, they know what to do when employees attend to such seminar, so that when employees will be assigned to do the task, at least they know how to handle it.

Workplace behavior leads to happy and satisfied employees who enjoy coming to work rather than treating it as a mere source of burden (managementstudyguide.com).

The three least priority of the non-teaching staff is presentation skills, research and extension, and instructional materials development. These imply that these are not that needed in their daily work. Like the presentation skills, there are still those who considered this to be attended because some are given teaching loads that they need to have this skill to perform better. Some are heads of units that need to be upskilled on this endeavor because sometimes they are asked to present their offices' reports.

Non-teaching staff is not banned in the university to research; however, the findings imply that very few are interested, and so with instructional materials development where only two were interested. It was found that these two are education graduates and have plans to go to teaching in the future which made them choose Instructional Materials Development seminar to attend to.

The findings imply that some of the KSU employees are not interested to join seminars that are not inclined to their works or line of specialization. This is in contrast with the results of an interview made to an employee who mentioned that it is more exciting to join seminars which are not in line with her specialization because according to her, she will be exploring new things and learn new endeavor aside from routine. This will make one broadminded and flexible. 
Table 3. Proposed Trainings/seminars for KSU Employees for 2020-2021

\begin{tabular}{|c|c|c|c|c|}
\hline Needs/Topics & $\begin{array}{c}\text { Date/Mo. of } \\
\text { Implementation }\end{array}$ & $\begin{array}{l}\text { Persons } \\
\text { involved }\end{array}$ & Participants & \# of Days \\
\hline 1. Strategic Planning/Org'l skills & January & CTPD & Faculty\& head of units & 2 \\
\hline $\begin{array}{ll}\text { 2. Stress Management/Mental } \\
\text { Health and Wellness }\end{array}$ & January & $\begin{array}{l}\text { CTPD, } \\
\text { HRMO }\end{array}$ & Faculty \& staff & 2 \\
\hline 3. Supervisory Skills & February & & $\begin{array}{c}\text { Faculty \& heads of } \\
\text { units }\end{array}$ & 1 \\
\hline 4. Presentation Skills & February & & $\begin{array}{c}\text { Faculty \& heads of } \\
\text { Units }\end{array}$ & 1 \\
\hline 5. Solid Waste Management & March & & All & 1 \\
\hline 6. Risk Reduction Management & March & & All & 1 \\
\hline 7. Compensation & April & & All & 1 \\
\hline $\begin{array}{lll}\text { 8. } & \begin{array}{l}\text { Employee } \\
\text { Management }\end{array} & \text { Performance }\end{array}$ & April & & All & 1 \\
\hline $\begin{array}{l}\text { 9. Climate change \& its risk to } \\
\text { environment }\end{array}$ & March & & All & 1 \\
\hline 10. Health and wellness & April & & All & 1 \\
\hline 11. 4.0 Industrial Technology & July & & & 2 \\
\hline 12. Research and Extension & May & & & 2 \\
\hline $\begin{array}{l}\text { 13. Instructional } \\
\text { Development }\end{array}$ & June & & & 2 \\
\hline 14. Orientation & July & & & 2 \\
\hline 15. Grievance Procedure & July & & & 1 \\
\hline 16. Costumer Service Skills & January & & All Non-teaching staff & 1 \\
\hline 17. Workplace Ethics & September & & & 1 \\
\hline 18. Conflict Management & August & & & 1 \\
\hline 19. Cultural Diversity & August & & & 1 \\
\hline 20. Workplace violence & September & & & 1 \\
\hline 21. Hiring \& firing Procedures & October & & & 1 \\
\hline 22. Recruitment and retention & November & & & 1 \\
\hline 23. Sexual Harassment & December & & & 1 \\
\hline
\end{tabular}

Based from the results of the study, the office of the Center for Training and Professional Development propose the following seminars to be implemented for the benefit of the Kalinga State University and the employees as well. When employees work safe and sound, they are more productive and at the end, the university and the community benefit with the outputs of these. 


\section{SUMMARY}

From the twenty-three training/seminars identified, the following are the top ten training needs: Strategic Planning/Org'l skills (182), Stress Management \& Supervisory Skills(181), Presentation Skills(164), Solid Waste Management(163), compensation (161), Employee Performance Management(160), Climate change \& its risk to the environment (138), Health and wellness for teachers(105), orientation (96), Instructional Materials Development(91), and Gender and Development(90). The less priority of employees was given schedules so that financial and time opportunities will also be considered and implemented.

\section{CONCLUSIONS}

Based from the findings of the study, the employees have various training needs. The faculty have different training needs compared to the non-teaching staff.

\section{RECOMMENDATIONS}

The following recommendations are: The administration is suggested to implement the employees' identified training needs through the office of the CTPD and the administration may consider a training center that can accommodate several participants for IGP and other purposes.

\section{REFERENCES}

[1] Abler, Rebecca. (, 2019). 2019 Research in Education. EDTOPIA.

[2] Averchenkova et al. (2019), Governance of climate change policy: A case study of South Africa. Policy publication 26 June 2019

[3] Beesley M, Cometto G, Pavignani E.(2011). From drought to deluge: how information overload saturated absorption capacity in a disrupted health sector. Health policy and planning.

[4] Derkach, Serhiy. (, 2018). Professional Training Needs of the Detectives of the National Anti-Corruption Bureau of Ukraine: Expert Opinion.

[5] Ghufli, Ali. (2009) "Training Needs Analysis (TNA): A case study of the Abu Dhabi Police" Doctoral Symposium.

[6] Greenberg, David. greenberg.rutgers.edu

[7] http://www.eSchoolToday.com/

[8] https://hr-guide.com/data/G510.htm

[9] https://managementhelp.org/training/systematic/needsassessment.htm

[10] https://managementhelp.org/training/systematic/needsassessment.htm

ISSN: 2456-7620

https://dx.doi.org/10.22161/ijels.56.85
[11] https://blog.wranx.com/what-are-the-benefits-of-customerservice-training

[12] https://www.thebalancecareers.com/conduct-a-simpletraining-needs-assessment-1919295

[13] https://www.managementstudyguide.com/training-needsassessment.htm

[14] https://oregonstate.edu/copyright

[15] Kugelberg S, Jonsdottir S, Faxelid E, Jonsson K, Fox A, Thorsdottir I, et al. (2012) Public health nutrition workforce development in seven European countries: constraining and enabling factors. Public health nutrition.

[16] Kumar A, Kumar P.(2013). Training needs assessment of service providers: targeted intervention for HIV/AIDS in Jharkhand, India. Journal of evidence-based social work.

[17] Lee, Laura (2019). Social and Emotional Learning. 2019 Research in Education.EDTOPIA

[18] Lin M, Santen SA, Yarris LM, Mullan P, Searle N, Rougas S, et al.(2012). Development of a training needs assessment for an education scholarship fellowship in emergency medicine. Academic Emergency Medicine. https://onlinelibrary.wiley.com/doi/full/10.1111/acem.12035.

[19] Leigh Dudley; copyright, Leigh Dudley.

[20] Managementstudyguide.com/importance-of-workplaceethics.htm

[21] Newbrander W, Peercy C, Shepherd-Banigan M, Vergeer P. (2012). A tool for assessing management capacity at the decentralized level in a fragile state. International Journal of Health Planning and Management.

[22] Nishad Nitin Vairagi | Smitil Dattatrey Patil | Pratibha M. Deshmukh. (, 2018). "Training Needs Analysis" Published in International Journal of Trend in Scientific Research and Development (IJTSRD), ISSN: 2456-6470, Volume-2 | Issue5, August 2018,

[23] URL: http://www.ijtsrd.com/papers/ijtsrd15759.pdf http://ww w.ijtsrd.com/computer-science/other/15759/training-needsanalysis/nishad-nitin-vairagi

[24] Wang Y, Li X, Yuan Y, Patel MS.(2014). A multi-method approach to curriculum development for in-service training in China's newly established health emergency response offices. PLoS ONE.

[25] www.techwalls.com 